AperTO - Archivio Istituzionale Open Access dell'Università di Torino

The Monviso Ophiolite Geopark, a Symbol of the Alpine Chain and Geological Heritage in Piemonte, Italy.

This is a pre print version of the following article:

Original Citation:

Availability:

This version is available http://hdl.handle.net/2318/147827

since 2017-05-22T10:12:31Z

Publisher:

Springer International Publishing Switzerland

Published version:

DOI:10.1007/978-3-319-09408-3_40

Terms of use:

Open Access

Anyone can freely access the full text of works made available as "Open Access". Works made available under a Creative Commons license can be used according to the terms and conditions of said license. Use of all other works requires consent of the right holder (author or publisher) if not exempted from copyright protection by the applicable law. 


\section{Metadata of the chapter that will be visualized in SpringerLink}

\begin{tabular}{|c|c|c|}
\hline Book Title & \multicolumn{2}{|c|}{ Engineering Geology for Society and Territory - Volume 8} \\
\hline \multicolumn{3}{|l|}{ Series Title } \\
\hline Chapter Title & \multicolumn{2}{|c|}{ The Monviso Ophiolite Geopark, a Symbol of the Alpine Chain and Geological Heritage in Piemonte, Italy } \\
\hline Copyright HolderName & \multicolumn{2}{|c|}{ Springer International Publishing Switzerland } \\
\hline \multirow[t]{8}{*}{ Corresponding Author } & Family Name & Rolfo \\
\hline & Given Name & Franco \\
\hline & Prefix & \\
\hline & Suffix & \\
\hline & Division & Department of Earth Sciences \\
\hline & Organization & $\mathrm{IGG}-\mathrm{CNR}$ \\
\hline & Address & 10125, Turin, Italy \\
\hline & Email & franco.rolfo@unito.it \\
\hline \multirow[t]{5}{*}{ Author } & Family Name & Balestro \\
\hline & Particle & \\
\hline & Given Name & Gianni \\
\hline & Prefix & \\
\hline & Suffix & \\
\hline \multirow{7}{*}{ Author } & Given Name & Alessandro \\
\hline & Prefix & \\
\hline & Suffix & \\
\hline & Division & Department of Earth Sciences \\
\hline & Organization & University of Torino \\
\hline & Address & 10125, Turin, Italy \\
\hline & Email & \\
\hline \multirow[t]{5}{*}{ Author } & Family Name & Castelli \\
\hline & Particle & \\
\hline & Given Name & Daniele \\
\hline & Prefix & \\
\hline & Suffix & \\
\hline
\end{tabular}




\begin{tabular}{|c|c|c|}
\hline & Division & Department of Earth Sciences \\
\hline & Organization & University of Torino \\
\hline & Address & 10125, Turin, Italy \\
\hline & Division & \\
\hline & Organization & $\mathrm{IGG}-\mathrm{CNR}$ \\
\hline & Address & 10125, Turin, Italy \\
\hline & Email & \\
\hline Author & Family Name & Ferrando \\
\hline & Particle & \\
\hline & Given Name & Simona \\
\hline & Prefix & \\
\hline & Suffix & \\
\hline & Division & Department of Earth Sciences \\
\hline & Organization & University of Torino \\
\hline & Address & 10125, Turin, Italy \\
\hline & Email & \\
\hline Author & Family Name & Groppo \\
\hline & Particle & \\
\hline & Given Name & Chiara \\
\hline & Prefix & \\
\hline & Suffix & \\
\hline & Division & Department of Earth Sciences \\
\hline & Organization & University of Torino \\
\hline & Address & 10125, Turin, Italy \\
\hline & Email & \\
\hline Author & Family Name & Mosca \\
\hline & Particle & \\
\hline & Given Name & Pietro \\
\hline & Prefix & \\
\hline & Suffix & \\
\hline & Division & \\
\hline & Organization & $\mathrm{IGG}-\mathrm{CNR}$ \\
\hline & Address & 10125, Turin, Italy \\
\hline & Email & \\
\hline Author & Family Name & Rossetti \\
\hline & Particle & \\
\hline & Given Name & Piergiorgio \\
\hline & Prefix & \\
\hline & Suffix & \\
\hline & Division & Department of Earth Sciences \\
\hline & Organization & University of Torino \\
\hline & Address & 10125, Turin, Italy \\
\hline & Email & \\
\hline Abstract & $\begin{array}{l}\text { The Mo } \\
\text { geodive }\end{array}$ & $\begin{array}{l}\text { (MOG) is one of the strateg } \\
\text { the research project "PROac }\end{array}$ \\
\hline
\end{tabular}


the PIEMONTE region". The MOG is an extraordinary well preserved ophiolite body in the Italian Western Alps. It is one of the best known relics of oceanic crust in the Alps and formed during opening of the Mesozoic western Alpine Tethys and underwent high pressure metamorphism during Alpine subduction. The MOG encompasses the whole lithological spectrum of the Piemonte-Ligurian ophiolites, i.e. metamorphosed peridotite, gabbro, dolerite, basalt, and cover sediments. The MOG gives the almost unique chance for everybody to see and appreciate different portions of the ancient ocean along a mountain trail; from the Po river springs at Pian del Re, to Lago Fiorenza, Lago Lausetto and Lago Superiore, a path rises from 2,000 up to about 2,350 m a.s.l. and shows all different ophiolitic lithologies within few kilometers. The inventory of a number of different geosites at the MOG, whose conservation and development require different expertises, is considered as the first and essential starting point for the geoconservation of geological heritage and geosites.

Keywords (separated by '-') Monviso massif - Cottian alps - Piemonte - Geological heritage 


\title{
The Monviso Ophiolite Geopark, a Symbol of the Alpine Chain and Geological Heritage in Piemonte, Italy
}

\author{
Franco Rolfo, Gianni Balestro, Alessandro Borghi, Daniele Castelli, \\ Simona Ferrando, Chiara Groppo, Pietro Mosca, and Piergiorgio Rossetti
}

\begin{abstract}
The Monviso Ophiolite Geopark (MOG) is one of the strategic geothematic areas chosen to represent the geodiversity of Piemonte within the research project "PROactive management of GEOlogical heritage in the PIEMONTE region". The MOG is an extraordinary well preserved ophiolite body in the Italian Western Alps. It is one of the best known relics of oceanic crust in the Alps and formed during opening of the Mesozoic western Alpine Tethys and underwent high pressure metamorphism during Alpine subduction. The MOG encompasses the whole lithological spectrum of the Piemonte-Ligurian ophiolites, i.e. metamorphosed peridotite, gabbro, dolerite, basalt, and cover sediments. The MOG gives the almost unique chance for everybody to see and appreciate different portions of the ancient ocean along a mountain trail; from the Po river springs at Pian del Re, to Lago Fiorenza, Lago Lausetto and Lago Superiore, a path rises from 2,000 up to about 2,350 $\mathrm{m}$ a.s.1. and shows all different ophiolitic lithologies within few kilometers. The inventory of a number of different geosites at the MOG, whose conservation and development require different expertises, is considered as the first and essential starting point for the geoconservation of geological heritage and geosites.
\end{abstract}

\section{Keywords}

Monviso massif • Cottian alps • Piemonte • Geological heritage

\subsection{Introduction and Aim of the Study}

Following the methodological approach of the ProGEO association (http://www.progeo.se), a multidisciplinary research group was created to carry out a research project ("PROactive management of GEOlogical heritage in the

F. Rolfo $(\bowtie) \cdot$ G. Balestro - A. Borghi · D. Castelli - S. Ferrando · C. Groppo · P. Rossetti

Department of Earth Sciences, University of Torino, 10125, Turin, Italy

e-mail: franco.rolfo@unito.it

F. Rolfo · D. Castelli · P. Mosca

IGG-CNR, 10125, Turin, Italy
PIEMONTE region") aiming to conceive new conceptual and operational protocols in the management of geoheritage in the Piemonte Region of NW Italy.

Within the project, the Monviso Ophiolite Geopark (MOG) is a strategic geothematic area chosen to represent the geodiversity of Piemonte and its high potential for scientific studies, enhancement of public understanding of science, recreation activities and economic support to local communities (Rolfo et al. 2014).

The MOG is a composite ophiolite body in the Italian Alps, and a prominent rocky pyramid, $3841 \mathrm{~m}$ high a.s.l. It gives a great chance to see and appreciate different portions of the ancient Tethys ocean along a mountain trail; from the Po river springs at Pian del Re, to Lago (lake) Fiorenza, Lago Lausetto and Lago Superiore, a path rises from 
2,000 $\mathrm{m}$ up to about 2,350 $\mathrm{m}$ a.s.l. and shows all different ophiolitic lithologies - modified after the Alpine evolutionwithin few kilometers.

\subsection{The Monviso Ophiolite Geopark}

\subsubsection{Geological Setting}

Ophiolites are portions of oceanic crust and underlying upper mantle, uplifted and emplaced onto continental crust in collisional orogens (e.g. Coleman 1977).

Among ophiolite bodies in the Alps, the MOG is one of the most representatives. It is a N-S trending body, $35 \mathrm{~km}$ long and up to $8 \mathrm{~km}$ wide, tectonically emplaced between the underlying continental-derived Dora-Maira thrust units and the ocean-derived Piemonte Zone metasedimentary units. The MOG, one of the best preserved relics of oceanic crust in the western Alps, formed during the Mesozoic opening of the western Alpine Tethys and underwent high pressure (eclogitic) metamorphism during Alpine subduction (e.g. Lombardo et al. 1978). The MOG encompasses the whole lithological spectrum of the Piemonte-Ligurian ophiolites: metamorphic rocks after former peridotite, gabbro, dolerite, basalt, as well as cover sediments, will thus be found (Fig. 40.1). Interestingly, the metagabbros derive from two types of protolith (Mg-Al-rich gabbro and Fe-Ti-rich gabbro) probably produced by fractional crystallization from tholeiitic melts at different fractionation stages (Lombardo et al. 1978).
$-62$ 63 64 65 -66 67 -68 69 70 71 72 73 74 75 76

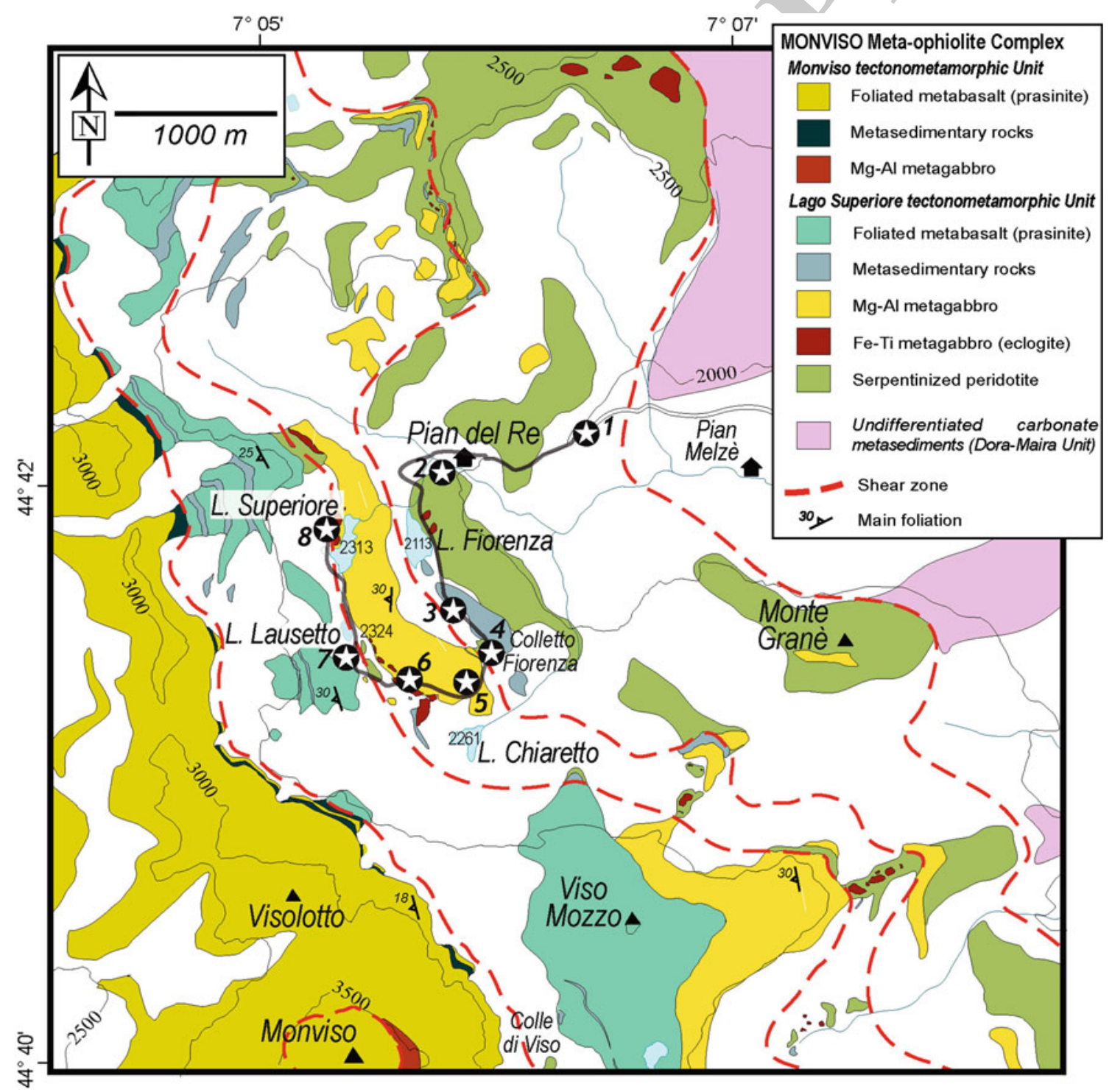

Fig. 40.1 Geological map of the Monviso Ophiolite Geopark in the Monviso-Pian Melzè area, with the excursion route and location of Stops 1-8 (in italics) described in the text (modified from Castelli et al. 2014) 
As a whole, the MOG comprises two major tectonometamorphic units, trending north-south and dipping to the west, separated by a major shear zone: the "Monviso Upper Unit" to the west (overturned according to its original geometry) and the "Lago Superiore Lower Unit" to the east (Castelli et al. 2014).

As concerning its geologic evolution, recent advances in petrology, geochemistry and geochronology all suggest a short duration of igneous activity in the MOG and a short time span (from ca 170 to ca $150 \mathrm{Ma}$ ) for the entire Piemonte-Ligurian Tethys, portraying a scenario with an embryonic ocean $(\max 380 \mathrm{~km}$ wide; Piccardo et al. 2001) rather than a mature, slow spreading, Atlantic-type ocean model (Lagabrielle and Cannat 1990). The oceanic crust preserved in the MOG experienced first an oceanic hydrothermal alteration (Nadeau et al. 1993) and then, during the Alpine subduction, an high pressure eclogite-facies metamorphism (e.g. Lombardo et al. 1978). Later exhumation produced re-equilibration under progressively lower pressure conditions at blueschist- and greenschist-facies.

\subsubsection{A Geologic Trail Across the Tethys Ocean}

A general view of the MOG internal structure is evident from a small hut along the road $(7.5 \mathrm{~km})$ from Pian Melzè to Pian del Re (Fig. 40.1, stop 1), by looking southward to the ridge from Monte Grané (2314 m) to Viso Mozzo (3019 m) and Monviso (3841 m). Along this section are exposed, from left to right and from bottom to top: the serpentinite at Monte Grané and in the lower ridge above Pian Melzè; the metagabbro at the foot of Viso Mozzo and the low ridge above Pian del Re; the Viso Mozzo metabasite and the Colle di Viso serpentinite, which crops out in the low ridge between Viso Mozzo and Monviso. This latter serpentinite sliver separates the two main tectonometamorphic units composing the MOG.

Along the path from Pian del Re to Lago Fiorenza, the first outcrop of serpentinite can be reached with a few minutes walk (Fig. 40.1, stop 2). The serpentinite, deriving from primary spinel-lherzolite of the upper mantle underlying the oceanic crust, is either massive or sheared (Fig. 40.2a). It mainly consists of antigorite, with variable amounts of clinopyroxene, brucite, Mg-rich chlorite, Ticlinohumite, metamorphic olivine and chrysotile; the ore minerals are magnetite, FeNi-alloys and sulphides. Different generations of metamorphic veins crosscut the serpentinite.

About 500 m SSE of Lago Fiorenza (Fig. 40.1, stop 3), the path crosses a folded elongated body of metasediments - originally covering the former oceanic crust - tectonically embedded within serpentinite. This sliver, about $50 \mathrm{~m}$-thick, belongs to an eclogite-facies shear zone which passes through Colletto Fiorenza. The metasediments consist of impure marbles, calcschists and micaschists grading to quartzite (Fig. 40.2b). Rare cm-thick layers of metabasite are interbedded with metasediments.

At Colletto Fiorenza (Fig. 40.1, stop 4), a tectonic contact between calcschists and the overlying metagabbro (Fig. 40.2c) is marked by a zone from a few $\mathrm{m}$ to a few tens of $\mathrm{m}$ thick of strongly sheared serpentinite and talccarbonate-amphibole-schist, with tectonic inclusions of banded eclogitic rocks.

Between Colletto Fiorenza and Lago Chiaretto (Fig. 40.1, stop 5), beautiful smaragdite metagabbro-former $\mathrm{Mg}$ Al-rich plutons in the lower oceanic crust-locally includes transposed $\mathrm{cm}$ - to dm-thick dykes of metabasalts. The metagabbro shows a well developed foliation and consists of a whitish matrix, in which emerald-green porphyroclasts of "smaragdite" (the local name for Cr-omphacite) are preserved (Fig. 40.2d). Locally, a layering in the smaragdite metagabbro suggests a cumulus structure. The greenish-gray to pinkish metabasaltic dykes, now eclogite, are very finegrained and locally preserve remnants of a porphyritic structure. Few boulders preserve igneous layering textures, with emerald-green bands (enriched in Cr-omphacite) corresponding to layers with high modal clinopyroxene.

West of the smaragdite metagabbro, along the path leading to Lago Lausetto and Rifugio Giacoletti, layered eclogitic rocks polished by the glacier are exposed (Fig. 40.1, stop 6). They consist of alternating layers of eclogite and metagabbro from a few $\mathrm{cm}$ - to several dm-thick. Eclogite largely prevails over metagabbro. The melanocratic layers (now eclogite) derive from primary FeTi-oxide gabbro, whereas leucocratic layers derive from $\mathrm{Mg}-\mathrm{Al}$ gabbro protoliths. The eclogitic foliation is cut by different generations of metamorphic veins.

South of Lago Lausetto, along the path leading to Rifugio Giacoletti (Fig. 40.1, stop 7), a narrow alluvial plane hides a shear zone separating Fe-Ti metagabbro mylonites (to the E) from foliated prasinite (to the $\mathrm{W}$ ). No primary features of the upper effusive portion of the oceanic crust, such as pillow structure or porphyritic texture, are preserved within the prasinite (nice pillows can be observed not far from here, for instance in the Vallone dei Duc, at the foot of Cima delle Lobbie). However, the prasinite may be considered as the metamorphic product of original basaltic flows. Homogeneous prasinite is fine-grained and mainly composed of albite, clinozoisite/epidote, chlorite, amphibole, and accessory rutile, titanite, apatite and opaque ores.

Finally, at the western side of Lago Superiore (Fig. 40.1, stop 8), a layered eclogitic sequence preserves small $(10 \times 10 \mathrm{~cm})$ lenses of low-strain domains still preserving the igneous microstructure and surrounded by large volumes of eclogite-facies mylonites. Cigar-shaped boudins of eclogite within the metagabbro outline a complex interference pattern of folds. Eclogite-facies veins are spectacular-and indeed 


\begin{tabular}{|l|lll|}
\hline Layout: T3 Standard Unicode & Book ID: 326582_1_En & Book ISBN: 978-3-319-09407-6 \\
Chapter No.: 40 & Date: 17-7-2014 & Time: 10:24 am & Page: 4/5 \\
\hline
\end{tabular}
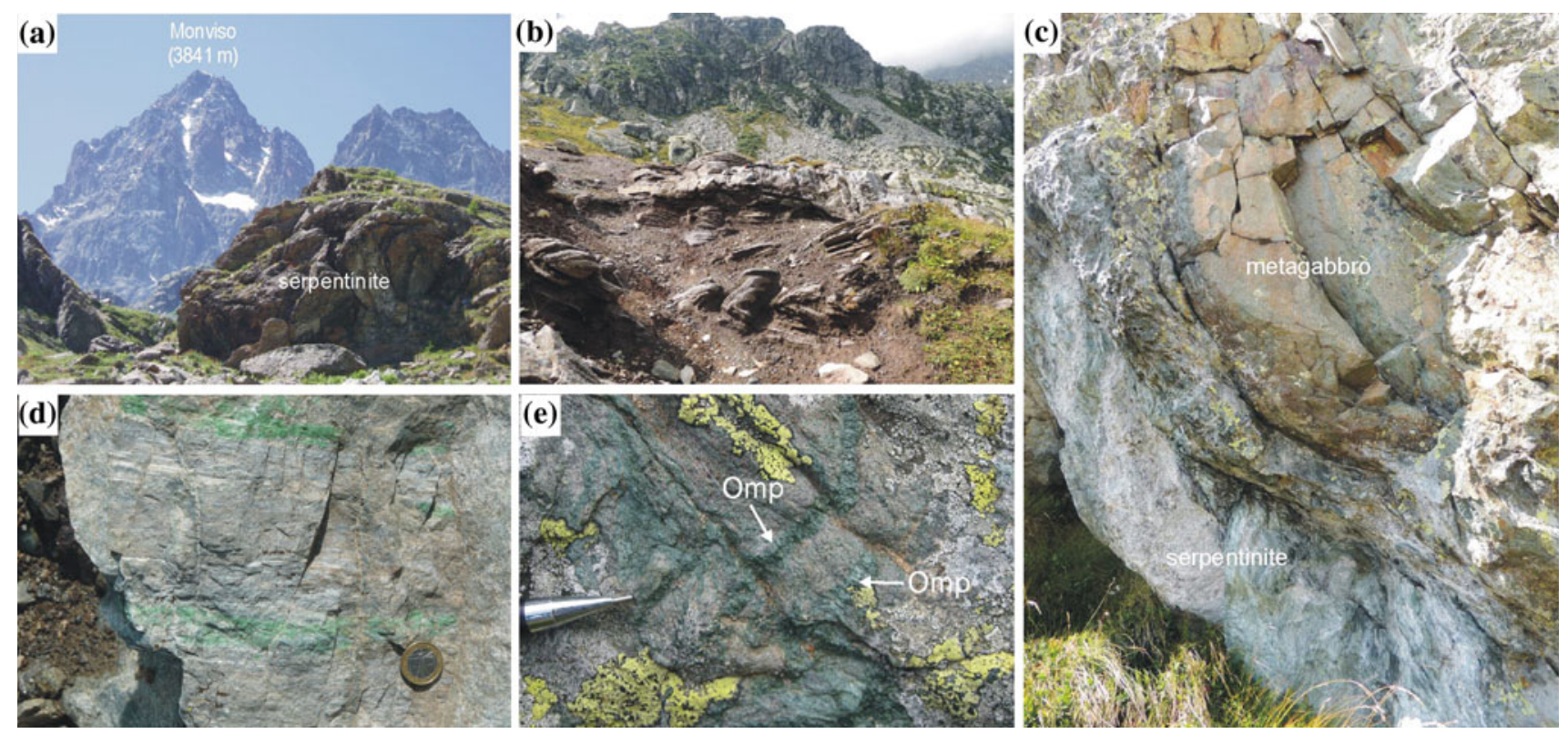

Fig. 40.2 a Stop 2: outcrop of serpentinite of the Basal Serpentinite Unit above Pian del Re; b Stop 3: folded calcschists and impure marbles of the Basal Serpentinite Unit; c Stop 4: contact between serpentinite and metagabbro at Colletto Fiorenza; d Stop 5: smaragdite

very rare worldwide - and witness the fluid migration during subduction (Fig. 40.2d). They contain mostly Na-pyroxene and minor garnet, rutile and apatite. In tension gashes, most pyroxene is fibrous.

\subsection{Perspectives}

A number of authors developed different methodologies and techniques for identifying, characterizing and managing geoheritage at the national, international and global scale (e. g. Wimbledon 1996). There is general agreement that the first and essential starting point for the geoconservation of geological heritage and geosites has to be an inventory of suitable resources and their detailed characterization and evaluation. Inventory and evaluation procedures play a decisive role on the implementation of subsequent conservation, valuing and monitoring of the geological heritage and may correspond to a sort of "Basic Geoconservation" (Henriques et al. 2011).

The inventory of a number of different geosites at the MOG, is provided here and further discussed by Rolfo et al. (2014). As concerning the geological concepts and geodiffusion interests we aim: (i) to show, describe and explain the preserved evidence of the fossil ocean; (ii) to explain the birth and development of an orogenic chain. Planned geodiffusion actions include concepts and design of geologic paths along the most interesting and representative cross metagabbro at Lago Chiaretto; e Stop 8: eclogite-facies omphacitebearing veins cross-cutting the eclogitic FeTi-oxide metagabbro foliation

sections, mostly devoted to show features of the palaeoocean floor.

After these first steps, further actions described in detail by Giardino et al. (2012) will include coupling of scientific concepts and techniques, together with products focused either on geosites and also on museum collections, science exhibits and nature trails.

Moreover, within the research project "PROactive management of GEOlogical heritage in the PIEMONTE region", multimedia and virtual reality approaches are planned, for imaging and communicating this unique natural heritage to an audience as broad as possible. Last but not least, further activity steps are the development of geodiversity action plans, including educational impacts and promotion of a "geodiversity economics".

\section{References}

Castelli D, Compagnoni R, Lombardo B, Angiboust S, Balestro G, Ferrando S, Groppo C, Rolfo F (2014) The monviso meta-ophiolite complex: HP metamorphism of oceanic crust and interactions with ultramafics. GFT-Geological Field Trips, pp 8-35 (in press). ISSN: $2038-4947$

Coleman RG (1977) Ophiolites: ancient oceanic lithosphere?. Springer Verlag, Berlin, p 229

Giardino M, The PROGEO-Piemonte Research Team (2012) A multidisciplinary research project for developing a PROactive management of GEOlogical heritage in the PIEMONTE Region. Geologia dell'Ambiente Suppl 3:196-197 
Henriques MH, Pena dos Reis R, Brilha J, Mota T (2011) Geoconservation as an emerging geoscience. Geoheritage 3:117-128

Lagabrielle Y, Cannat M (1990) Alpine Jurassic ophiolites resemble the modern central Atlantic basement. Geology 18:319-322

Lombardo B, Nervo R, Compagnoni R et al (1978) Osservazioni preliminari sulle ofioliti metamorfiche del Monviso (Alpi Occidentali). Rend Soc It Mineral Petrol 34:253-305

Nadeau S, Philippot P, Pineau F (1993) Fluid inclusion and mineral isotopic compositions (H-O-C) in eclogitic rocks as tracers of local fluid migration during high-pressure metamorphism. Earth Planet Sci Lett 114:431-448
Piccardo GB, Rampone E, Romairone A, Scambelluri M, Tribuzio R, Beretta C (2001) Evolution of the ligurian tethys: inference from petrology and geochemistry of the ligurian ophiolites. Per Mineral 70:147-192

Rolfo F, Benna P, Cadoppi P et al (2014) The Monviso massif and the cottian alps as symbols of the alpine chain and geological heritage in Piemonte, Italy. Geoheritage, in press. doi:10.1007/s12371-0140097-9

Wimbledon WAP (1996) GEOSITES, a new IUGS initiative to compile a global comparative site inventory, an aid to international and national conservation activity. Episodes 19:87-88
245 


\section{Author Query Form}

\section{Book ID : 326582_1_En}

Chapter No.: $\mathbf{4 0}$
Springer

the language of sciénce

Please ensure you fill out your response to the queries raised below and return this form along with your corrections

Dear Author

During the process of typesetting your chapter, the following queries have arisen. Please check your typeset proof carefully against the queries listed below and mark the necessary changes either directly on the proof/online grid or in the 'Author's response' area provided below

\begin{tabular}{|l|l|l|}
\hline Query Refs. & Details Required & Author's Response \\
\hline AQ1 & No Queries & \\
\hline
\end{tabular}




\section{Please correct and return this set}

Please use the proof correction marks shown below for all alterations and corrections. If you wish to return your proof by fax you should ensure that all amendments are written clearly in dark ink and are made well within the page margins.

\begin{tabular}{|c|c|c|}
\hline Instruction to printer & Textual mark & Marginal mark \\
\hline Leave unchanged & ... under matter to remain & ( ) \\
\hline $\begin{array}{l}\text { Insert in text the matter } \\
\text { indicated in the margin }\end{array}$ & $h$ & $\begin{array}{l}\text { New matter followed by } \\
h \text { or } h \otimes\end{array}$ \\
\hline Delete & $\begin{array}{l}\text { I through single character, rule or underline } \\
\text { or }\end{array}$ & $\sigma$ or $\sigma / 2$ \\
\hline $\begin{array}{l}\text { Substitute character or } \\
\text { substitute part of one or } \\
\text { more word(s) }\end{array}$ & I through letter or & $\begin{array}{l}\text { new character / or } \\
\text { new characters / }\end{array}$ \\
\hline Change to italics & — under matter to be changed & $\leftarrow$ \\
\hline Change to capitals & $\equiv$ under matter to be changed & $\equiv$ \\
\hline Change to small capitals & $=$ under matter to be changed & $=$ \\
\hline Change to bold type & $\sim$ under matter to be changed & $\sim$ \\
\hline Change to bold italic & $\bar{\sim}$ under matter to be changed & 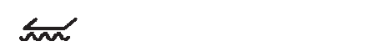 \\
\hline Change to lower case & Encircle matter to be changed & $\Rightarrow$ \\
\hline Change italic to upright type & (As above) & \\
\hline Change bold to non-bold type & (As above) & nor \\
\hline Insert 'superior' character & $\begin{array}{l}/ \text { through character or } \\
\alpha \text { where required }\end{array}$ & $\begin{array}{l}y^{\prime} \text { or } y \\
\text { under character } \\
\text { e.g. } y^{2} \text { or } y^{2}\end{array}$ \\
\hline Insert 'inferior' character & (As above) & $\begin{array}{l}\lambda \\
\text { over character } \\
\text { e.g. } \hat{\Sigma}\end{array}$ \\
\hline Insert full stop & (As above) & $\odot$ \\
\hline Insert comma & (As above) & , \\
\hline Insert single quotation marks & (As above) & $\begin{array}{l}\dot{y} \text { or } \dot{x} \text { and/or } \\
\dot{y} \text { or } \dot{y}\end{array}$ \\
\hline Insert double quotation marks & (As above) & $\begin{array}{l}\ddot{y} \text { or } \ddot{x} \text { and/or } \\
\ddot{y} \text { or } \ddot{x}\end{array}$ \\
\hline Insert hyphen & (As above) & 1 \\
\hline Start new paragraph & 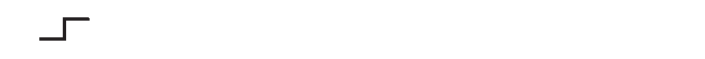 & 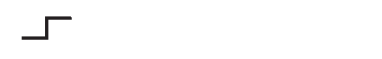 \\
\hline No new paragraph & $\omega$ & 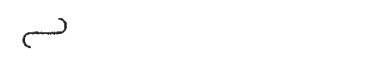 \\
\hline Transpose & $\sqcup$ & $\sqcup$ \\
\hline Close up & linking $\bigcirc$ characters & \\
\hline $\begin{array}{l}\text { Insert or substitute space } \\
\text { between characters or words }\end{array}$ & $\begin{array}{l}\text { I through character or } \\
\Lambda \text { where required }\end{array}$ & \\
\hline $\begin{array}{l}\text { Reduce space between } \\
\text { characters or words }\end{array}$ & $\begin{array}{l}\text { between characters or } \\
\text { words affected }\end{array}$ & $T$ \\
\hline
\end{tabular}

